\title{
REVIEW
}

\section{Glucocorticoids and fatty acid metabolism in humans: fuelling fat redistribution in the metabolic syndrome}

\author{
David P Macfarlane, Shareen Forbes and Brian R Walker \\ Endocrinology Unit, Queen's Medical Research Institute, Centre for Cardiovascular Science, University of Edinburgh, 47 Little France Crescent, Edinburgh \\ EH16 4TJ, Scotland, UK \\ (Correspondence should be addressed to B R Walker; Email: b.walker@ed.ac.uk)
}

\begin{abstract}
Glucocorticoid hormones constitute an integral component of the response to stress, and many of the manifestations of glucocorticoid excess (Cushing's syndrome) are predictable on the basis of their acute effects to raise blood pressure, induce insulin resistance, increase protein catabolism and elevate plasma glucose. However, it appears to be a paradox that the acute lipolytic effect of glucocorticoids is not manifest in long-term weight loss in humans. The effects of glucocorticoids on glucose metabolism are well characterised, involving impaired peripheral glucose uptake and hepatic insulin resistance, and there is mounting evidence that subtle abnormalities in glucocorticoid concentrations in the plasma and/or in tissue sensitivity to
\end{abstract}

glucocorticoids are important in metabolic syndrome. The effects of glucocorticoids on fatty acid metabolism are less well understood than their influence on glucose metabolism. In this article, we review the literature describing the effects of glucocorticoids on fatty acid metabolism, with particular reference to in vivo human studies. We consider the implications for contrasting acute versus chronic effects of glucocorticoids on fat accumulation, effects in different adipose depots and the potential role of glucocorticoid signalling in the pathogenesis and therapy of metabolic syndrome.

Journal of Endocrinology (2008) 197, 189-204

\section{Introduction}

Endogenous glucocorticoids are steroid hormones secreted from the adrenal cortex under the influence of the hypothalamic-pituitary-adrenal (HPA) axis that constitutes an integral component of the response to stress. Corticosterone is the principal glucocorticoid in most rodents that lack the enzyme $17 \alpha$-hydroxylase in the adrenal necessary for the hydroxylation of pregnenolone and hence the synthesis of cortisol, the main glucocorticoid in humans.

Endogenous and exogenous glucocorticoids, like other steroid hormones, act on intracellular receptors to influence the transcription of target genes. The glucocorticoid receptor (GR or type 2 corticosteroid receptor) has a widespread tissue distribution, whereas the mineralocorticoid receptor (MR or type 1 corticosteroid receptor) is localised to specific anatomical sites, including the distal nephron, colon and sweat glands (Edwards et al. 1988, Seckl \& Walker 2001). Pre-receptor metabolism of glucocorticoids determines tissue-specific sensitivity, such that MR is protected from glucocorticoid activation by the enzyme $11 \beta$-hydroxysteroid dehydrogenase type $2(11 \beta-$ HSD2) that converts active cortisol to inactive cortisone in humans, whereas GR activation can be amplified by the enzyme $11 \beta-H S D 1$, a ketoreductase in vivo catalysing the reverse reaction (Seckl \& Walker 2001).

In addition to their role in cellular growth and development, glucocorticoids have multi-systemic effects that are essential for survival in times of stress, influencing the regulation of blood pressure, salt and water balance, immune function and cellular energy metabolism. In the short term, these acute effects contribute to adaptive responses. For example, glucocorticoids are catabolic, increasing the availability of substrates for mitochondrial oxidation (from glucose, amino acids and fatty acids). The consequences of failure of these adaptive responses are clearly demonstrated in the syndrome of adrenal insufficiency (in Addison's disease or adrenocorticotrophin, ACTH deficiency), characterised by lethargy, weight loss and postural hypotension, in which severe stress or sepsis can be lifethreatening (Addison 1855). If sustained in the long term, however, the effects of glucocorticoids may become maladaptive. Chronic glucocorticoid excess (Cushing's syndrome) leads to morbidity and mortality through a variety of factors, including obesity, osteoporosis, hypertension, hyperglycaemia and impaired response to infection (Cushing 1912). These 
chronic adverse effects are important, not least because large numbers of patients receive treatment with synthetic glucocorticoids for a wide range of inflammatory conditions such as rheumatoid arthritis and asthma (Wei et al. 2004).

Although many of the manifestations of Cushing's syndrome are predictable on the basis of the acute effects of glucocorticoids (e.g. to raise blood pressure, induce insulin resistance, promote skeletal muscle wasting and elevate plasma glucose), it appears to be a paradox that the acute lipolytic effect of glucocorticoids is not manifest in long-term weight loss in Cushing's syndrome. Indeed, chronic glucocorticoid excess in rodents usually induces weight loss rather than weight gain (Elliott et al. 1971), and some limited studies in humans with Cushing's syndrome suggest that lipolytic rates are reduced or unaltered, rather than enhanced (Birkenhager et al. 1976, Saunders et al. 1980). Moreover, in Cushing's syndrome, there is marked redistribution of body fat, with accumulation in the depots in the abdomen, the nape of the neck and cheeks, but wasting of fat in many s.c. adipose compartments. There may also be excessive accumulation of triglycerides in 'ectopic' sites such as the liver in Cushing's syndrome (Mayo-Smith et al. 1989). This pattern of central fat accumulation, associated with glucose intolerance and hypertension, results in remarkable similarities between the clinical features of Cushing's syndrome and those of the metabolic syndrome (Reaven \& Hoffman 1987). Indeed, there is mounting evidence that subtle abnormalities in glucocorticoid concentrations in the plasma and/or in tissue sensitivity to glucocorticoids are important in metabolic syndrome, as recently reviewed elsewhere (Walker 2006, 2007).

The effects of glucocorticoids on glucose metabolism are well characterised and have been reviewed in detail previously (Andrews \& Walker 1999). For many genes involved in glucose metabolism, glucocorticoid effects oppose those of insulin. As a result, glucocorticoids induce a state of insulin resistance, leading to diminished suppression of glucose production and reduced peripheral glucose uptake (Rizza et al. 1982). Glucocorticoids may also reduce glucose delivery to some tissues by impairing local blood flow (Mangos et al. 2000). In addition, glucocorticoids suppress insulin secretion relative to the degree of hyperglycaemia (Dinneen et al. 1993), reducing basal pulsatility of insulin secretion (Hollingdal et al. 2002). These anti-insulin effects favour hyperglycaemia, putatively to fuel non-insulindependent glucose uptake and oxidation in the brain and active skeletal and cardiac muscles. Similarly, in Cushing's syndrome, reduced peripheral glucose uptake and hepatic insulin resistance are predominant features (Reinartz et al. 1995, Heaney et al. 1997). However, glucocorticoids do not oppose insulin action on glucose metabolism in all respects, for example, they enhance 'futile' cycling between glucose and glucose-6-phosphate and simultaneously stimulate both glycogen synthesis and glycogenolysis (Andrews \& Walker 1999). As a result, glucocorticoids do not simply increase plasma glucose directly but they also enhance the magnitude of the acute response to other counterregulatory stimuli, including catecholamines (Dallman et al. 1993). In a low insulin environment, for example, during starvation in acute stress, the result is a more effective release of fuel. However, in a high insulin environment, for example, with re-feeding during recovery from stress, glucocorticoids may promote glycogen re-accumulation.

The effects of glucocorticoids on fatty acid metabolism are less well understood than those on glucose metabolism and have not been reviewed in detail. In this article, we review the literature describing the effects of glucocorticoids on fatty acid metabolism, with particular reference to in vivo human studies. We consider the implications for contrasting acute versus chronic effects of glucocorticoids on fat accumulation, contrasting effects in different adipose depots and the potential role of glucocorticoid signalling in the pathogenesis and therapy of metabolic syndrome.

\section{Fatty acid metabolism}

Along with glucose, non-esterified (or free) fatty acids (NEFAs) are a major source of fuel for oxidative metabolism, especially in cardiac and skeletal muscles during the postabsorptive period (Coppack et al. 1994). They have additional roles in membrane function and structure, including prostaglandin synthesis.

\section{Overview of NEFA metabolism}

Trafficking and metabolism of NEFAs are summarised in Fig. 1. NEFAs are insoluble in plasma and therefore must be complexed to albumin or esterified with glycerol to triacylglycerides (TAGs) and packaged in lipoprotein particles for transport in the circulation (Spector 1975). The majority of fatty acids in humans are derived from dietary sources and stored as TAGs in adipose tissue, or in small amounts in liver and muscle. De novo lipogenesis (DNL) is an additional source of NEFAs (Hellerstein 1999). Circulating chylomicron and very-low-density lipoprotein (VLDL) TAGs, delivered from the gut and liver respectively, are hydrolysed by lipoprotein lipase (LPL) located on the luminal surface of the capillary endothelium (Linder et al. 1976). This allows NEFAs to be taken up into cells, either by a passive or by a facilitated process (Garfinkel et al. 1976, Kalant \& Cianflone 2004), and then re-esterified to TAGs within tissues. However, NEFAs released from circulating TAGs can also spillover into the plasma NEFA pool without prior transportation into tissues (Coppack et al. 1992), and recent data suggest that direct uptake of circulating NEFAs from plasma may also occur (Kratky et al. 2005).

TAGs form an efficient energy store, containing more than twice as many calories as glycogen or protein per gram, with less water content (Hillgartner et al. 1995), and are hydrolysed to release NEFAs and glycerol (plus di- and monoacylglyceride intermediates), a process known as lipolysis. Complete lipolysis of TAGs yields three fatty acids and one glycerol molecule. As adipose tissue lacks the enzyme glycerol kinase required to transport glycerol back into the adipocyte, the appearance of glycerol in the systemic circulation is a direct 


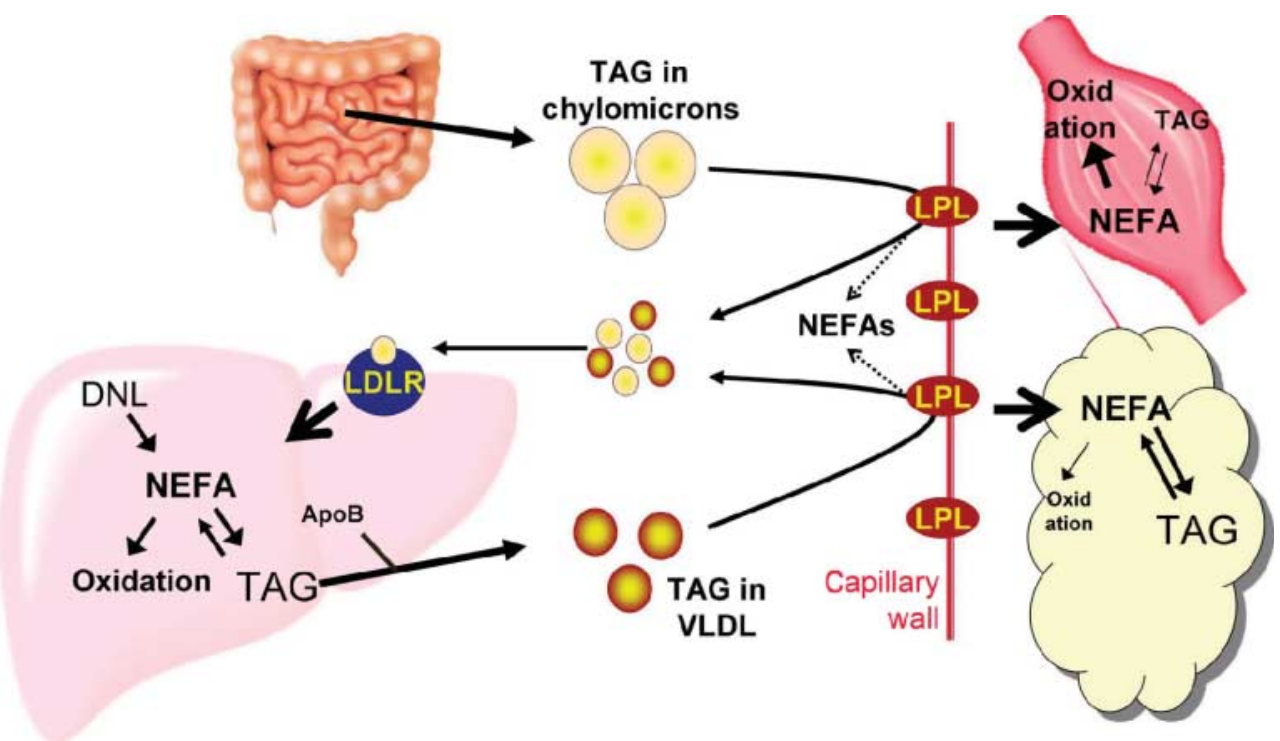

Figure 1 Overview of non-esterified fatty acid (NEFA) and triacylglyceride (TAG) trafficking.

measurement of adipose tissue lipolysis. There are two fates for the NEFAs mobilised from stored TAGs: one is $\beta$-oxidation within the mitochondria to generate ATP and the other is re-esterification to TAGs. As NEFA release generally exceeds their oxidation, re-esterification to TAGs is a key factor regulating NEFA levels, for example, in the liver where NEFAs can be incorporated into VLDL TAG (Coppack et al. 1994). Furthermore, for fat accumulation to occur, rates of re-esterification and/or DNL must exceed those of lipolysis and $\beta$-oxidation at that site.

Until recently, hormone-sensitive lipase (HSL) was believed to be the main enzyme responsible for adipose tissue lipolysis (Miyoshi et al. 1988). However, it is now apparent that HSL acts to hydrolyse diacylglycerides released following prior hydrolysis of the first TAG ester bond by adipose triacylglyceride lipase (ATGL; Zimmermann et al. 2004). A number of excellent recent review articles discuss this discovery in detail (Zechner et al. 2005, Jaworski et al. 2007). Single nucleotide polymorphisms in the gene encoding ATGL are associated with increased risk of type 2 diabetes, providing support for a role of abnormalities of lipolysis in the pathogenesis of insulin resistance (Schoenborn et al. 2006).

\section{Acute regulation of fatty acid metabolism}

Given their central role in the crucial process of cellular energy provision, it is not surprising that fatty acid metabolism is tightly regulated. The processes controlling the switch between predominant lipolysis/fatty acid oxidation during fasting and predominant lipid storage/glucose oxidation following feeding are determined principally by insulin and catecholamines as follows.

Adipose and intravascular lipolysis Lipolysis is closely regulated in a reciprocal, tissue-specific manner such that following a meal, when glucose and chylomicrons are in abundant supply, adipose tissue LPL is upregulated, whereas its activity in muscle is suppressed (Fielding \& Frayn 1998). Insulin is the major hormone encouraging lipolysis of circulating TAG-rich lipoproteins, while also suppressing the release of NEFAs from adipose tissue (Coppack et al. 1994) and promoting re-esterification of NEFAs within adipocytes (Campbell et al. 1992). In contrast, during the post-absorptive period, when insulin levels are low, circulating adrenaline and locally produced noradrenaline are the main stimulators of adipose tissue lipolysis (Coppack et al. 1994).

Additional paracrine, autocrine and hormonal factors may be important in regulating lipolysis but their significance in vivo is less clear. In vitro studies suggest that the regulation of LPL expression and activity is complex (reviewed in Mead et al. 2002), and occurs in part by post-translational modification (Ong \& Kern 1989). Furthermore, local conditions including blood flow may influence the efficiency of lipoprotein metabolism by LPL (Coppack et al. 1994), and hence the degree of spillover of NEFAs into the circulation (Samra et al. 1996b).

De novo lipogenesis Acetyl-CoA carboxylase and fatty acid synthase are the two key enzymes catalysing DNL and require an ample supply of substrates including acetyl-CoA, NADPH and ATP to allow the synthesis of NEFAs (Berdanier 1989). Both liver and adipose tissue are capable of synthesising fatty acids de novo. However, although the biosynthetic pathways of DNL are well characterised, and rodent studies suggest that a large number of regulatory dietary and hormonal factors may be important (reviewed by Hillgartner et al. 1995), the physiological significance of factors influencing DNL in humans is less clear. Indeed, except during embryogenesis and lactation, the importance of DNL as a source of lipids is a matter of debate (Hellerstein 1999). Broadly speaking, 
however, insulin promotes DNL, whereas adrenaline, glucagon and NEFAs themselves inhibit DNL (Hillgartner et al. 1995).

Mitochondrial $\boldsymbol{\beta}$-oxidation Mitochondrial $\boldsymbol{\beta}$-oxidation is essentially the reverse process of lipogenesis, producing acetylCoA and ATP. However, whereas lipogenesis is a cytosolic process, before oxidation NEFAs first must be converted to acylCoA intermediates and transferred into mitochondria (McGarry \& Brown 1997). Carnitine palmitoyl transferase 1 (CPT1) undertakes this transport process, and is the ratelimiting initial step in NEFA oxidation. Its activity is tightly regulated such that malonyl-CoA, the principle intermediate in DNL, inhibits CPT1 (Zammit 1999). Therefore, factors influencing lipogenesis also influence mitochondrial oxidation, with insulin-inhibiting and adrenaline-stimulating oxidation of NEFAs; these factors also influence substrate availability for oxidation (Blaak et al. 1994, Sidossis et al. 1996).

Hepatic VLDL metabolism The liver acts as an important buffer for NEFAs, temporarily storing them in the cytosolic TAG pool prior to transport/cycling back to adipose tissue stores by VLDL (Gibbons et al. 2004). Hepatic VLDL assembly and secretion is a complex and incompletely understood process intimately associated with apolipoprotein B metabolism (reviewed elsewhere, Olofsson \& Boren 2005). In simplistic terms, insulin acts to inhibit VLDL assembly and secretion directly, while also reducing glucose and portal NEFA flux, which normally promote VLDL export postprandially (Gibbons et al. 2002).

\section{Long-term regulation of fatty acid metabolism}

The physiological control of energy metabolism requires us to achieve not only appropriate responses to acute feeding and fasting but also appropriate longer term adaptations to the nutritional environment. Longer term regulators of fatty acid metabolism are less well understood than the acute adaptations, which accompany the normal daily cycle of fasting and feeding. Growth hormone $(\mathrm{GH})$, although not as potent and rapidly acting as adrenaline, may be important during exercise and fasting, increasing adipose lipolysis over a period of $2-3 \mathrm{~h}$ (Moller et al. 1990). However, chronic GH deficiency is associated with accumulation of TAG in adipose tissue (Rosen et al. 1993). More recently, there has been interest in macrophage-derived cytokines, for example, interleukin-6, and tumour necrosis factor $\alpha$ modulating adipose tissue lipolysis, although their physiological significance remains unclear (van Hall et al. 2003, Jensen 2003). Other stimulators of lipolysis include thyroid-stimulating hormone, parathyroid hormone and cholecystokinin, all of which act through G-coupled receptors. Inhibitors of lipolysis include insulin-like growth factor-I, adenosine, $\alpha$-adrenergic agonists and prostaglandin $E_{2}$, (Coppack et al. 1994).

Members of the nuclear hormone receptor family play a key role in 'setting the scene' for metabolic control in the longer term. These include peroxisome proliferator-activating receptors (PPARs) and sex steroid receptors, which may exert their effects by altering adipocyte differentiation as much as by altering fatty acid metabolism. The potency of these effects is illustrated by the dramatic differences in fatty acid metabolism between men and women (Koutsari \& Jensen 2006) and by the effects of PPAR $-\gamma$ agonists on fat distribution (Shadid \& Jensen 2003).

GRs are also expressed in adipose tissue and liver and glucocorticoids may be important in both the acute and chronic regulation of fatty acid trafficking and metabolism, and in influencing adipose tissue differentiation and function.

\section{Glucocorticoid effects on fatty acid metabolism}

The ideal studies of glucocorticoid action would be conducted during both short- (h/days) and long-term (weeks) steroid administration in vivo with detailed measurements of VLDL and fatty acid turnover, including in multiple s.c. and visceral adipose depots. Unfortunately, very few ideal studies have been conducted and findings in the literature are somewhat inconsistent. The emphasis has been on investigating effects on lipolysis, but glucocorticoids have important effects on adipocyte differentiation and may also regulate DNL and mitochondrial $\beta$-oxidation, as well as affecting appetite and the supply of chylomicron-TAG from food.

\section{Effects of glucocorticoids on adipose tissue and intravascular lipolysis}

Acute in vitro studies A great deal of effort has been expended on studies in cells in culture, which may or may not reflect measurements undertaken in vivo (Lillioja et al. 1986). Re-esterification is also difficult to interpret in vitro due to factors such as the concentration of albumin in the culture medium (Edens et al. 1990). Most importantly, adipocyte differentiation in vitro is dependent on the high concentrations of insulin and glucocorticoids, so that many of the effects ascribed to direct 'regulation' of gene transcription may in fact be indirect manifestations of the change in cellular phenotype in the presence of glucocorticoids. Nevertheless, in vitro studies have generally shown increased NEFA release from adipocytes in response to glucocorticoids (reviewed in Baxter \& Forsham 1972). Cortisol has also been shown to amplify the induction of lipolysis by catecholamines in cells primed with GH, but in the presence of insulin, it reduced the basal lipolytic rate and responsiveness to catecholamines (Ottosson et al. 2000).

Both HSL (Slavin et al. 1994) and ATGL are induced by glucocorticoids (Villena et al. 2004). In human adipocytes, LPL activity and mRNA expression are also increased by glucocorticoids with differences between sexes and adipose depots studied (Ong et al. 1992, Fried et al. 1993). Omental adipose tissue has a higher concentration of GRs (RebufféScrive et al. 1990) and showed a greater response to dexamethasone than s.c. fat, especially in men (Fried et al. 1993). 
Synergistic increases in LPL activity in response to insulin and dexamethasone were seen in both depots and were not fully explained by increased mRNA transcription, suggesting posttranslational modification of LPL in the presence of glucocorticoids, for example, reducing LPL degradation (Appel \& Fried 1992). Conversely, the glucocorticoid antagonist RU38486 reduced adipose LPL activity in vitro (Ottosson et al. 1995).

These findings suggest that glucocorticoids may increase both the uptake and turnover of fatty acids in adipose tissue and, analogous to their effects to increase glucose/glycogen turnover, may modulate the dynamic responsiveness to other stimuli such as insulin or catecholamines.

Acute in vivo studies A variety of techniques are commonly employed to study lipid metabolism in vivo. Fatty acid turnover can be measured using isotope dilution techniques involving infusion of stable or radioactive isotopomers of fatty acids (e.g. ${ }^{13} \mathrm{C}_{1}$-palmitate) and whole body lipolysis can also be estimated using glycerol tracers to measure rates of appearance $\left(R_{\mathrm{a}}\right)$ (Wolfe \& Peters 1987). Regional rates of lipolysis can be assessed by arteriovenous (A-V) sampling or microdialysis techniques measuring glycerol concentrations (Frayn et al. 1997). To minimise the influence of other hormones on lipolysis, a pancreatic clamp can be employed by infusing somatostatin, with controlled insulin, GH and occasionally glucagon replacement.

Results of short-term infusions of glucocorticoids suggest that lipolysis is increased, as in the in vitro experiments, but that there are counter-regulatory effects mediated by other hormones. Thus, using a pancreatic clamp with very low-dose insulin replacement, the Mayo Clinic group demonstrated a $60 \%$ increase in the $R_{\mathrm{a}}$ of palmitate in response to hydrocortisone infusion after $4-5 \mathrm{~h}$, clearly demonstrating the potential of glucocorticoids to promote adipose tissue lipolysis (Divertie et al. 1991). Plasma cortisol concentrations reached $970 \mathrm{nmol} / 1$, a level above the 'normal' physiological range, but consistent with the stressed state. In contrast, without a pancreatic clamp Dinneen et al. (1993) mimicked physiological cortisol concentrations using a combination of metyrapone (to reduce glucocorticoid production) and variable hydrocortisone infusion for $15 \mathrm{~h}$, and showed no difference in the fasting $R_{\mathrm{a}}$ of palmitate during relative hypercortisolaemia, although only a single premeal measurement was taken, so subtle changes could have been missed. However, hypercortisolaemia did increase the $R_{\mathrm{a}}$ of palmitate after a mixed meal, despite a higher post-prandial insulin response suggesting resistance to the inhibition of lipolysis by insulin (Dinneen et al. 1993). It is not possible to delineate whether the observed increase in the $R_{\mathrm{a}}$ of palmitate was secondary to adipose tissue lipases or increased NEFA spillover from LPL acting on circulating TAG, but it appears that cortisol does increase NEFA release from circulating TAGs (Samra et al. 1998), suggesting a combination of increased LPL activity and increased adipose lipolysis during acute hypercortisolaemia.

Studies without tracer infusion have demonstrated that adrenaline and cortisol have synergistic effects on NEFA concentrations during somatostatin administration (Pernet et al. 1986), but have no effect on the anti-lipolytic effect of insulin during hyperinsulinaemia $\left(20 \mathrm{mU} / \mathrm{m}^{2}\right.$ per min; Clerc et al. 1986). Both GH and glucocorticoids may influence sensitivity to adrenaline by reducing anti-lipolytic $\alpha_{2}$-adrenoreceptor availability (Yip \& Goodman 1999, Djurhuus et al. 2004), but acute in vivo studies have demonstrated additive independent effects of $\mathrm{GH}$ and cortisol on lipolysis during a pancreatic clamp, suggesting separate mechanisms of action (Djurhuus et al. 2004). Perhaps crucially, glucocorticoids also increase pro-lipolytic $\beta$-adrenergic receptor numbers via GR-dependent mechanisms (Nakada et al. 1987, Lacasa et al. 1988).

Several investigators have explored differences in glucocorticoid effects in different regions of body fat, with somewhat inconsistent results. Samra et al. (1998) induced supraphysiological plasma cortisol concentrations of $\sim 1500 \mathrm{nmol} / 1$ and measured increased systemic rates of lipolysis. However, s.c. adipose tissue lipolysis (measured by $\mathrm{A}-\mathrm{V}$ difference in the anterior abdominal wall) was reduced and LPL activity (calculated from adipose tissue blood flow and TAG extraction) was not altered (Samra et al. 1998), suggesting that the s.c. adipose tissue may be excluded from the acute lipolytic effect of cortisol. However, Djurhuus et al. (2002), who also measured increased systemic rates of lipolysis, found contradictory results using microdialysis techniques: s.c. adipose lipolysis was increased in both abdominal and leg adipose compartments in response to hypercortisolaemia $(\sim 900 \mathrm{nmol} / \mathrm{l})$ during a pancreatic clamp with low-dose insulin replacement (Djurhuus et al. 2002). The discrepancies between these studies are most likely explained by the higher insulin levels in the study by Samra et al. (1998). The key experiment, comparing glucocorticoid effects on lipolysis in s.c. and visceral adipose tissue depots, has not yet been reported.

Further in vivo support for an acute effect of cortisol on lipolysis comes from studies blocking glucocorticoid release. Plasma cortisol levels follow a diurnal rhythm, peaking 2-4 h before wakening in humans, and reaching a nadir around midnight. Studies have confirmed that these physiological variations in cortisol influence fuel availability at a tissue level, by demonstrating reduced s.c. adipose tissue lipolysis and LPL activity (by A-V difference technique) following abolition of the morning rise in cortisol using metyrapone (Samra et al. 1996a). No effect of glucocorticoids on adipose tissue blood flow or NEFA re-esterification rates was demonstrated (Samra et al. 1996a).

These results imply that acute elevations of cortisol within the normal physiological range can modulate adipose tissue function. In particular, the effects on lipolysis may be most important when insulin levels are low, for example, in patients with diabetes (Schade et al. 1978, Johnston et al. 1982) and when adrenaline levels are high. How this control is modulated in different adipose tissue depots remains, however, uncertain.

Chronic studies The above acute in vivo studies examined lipolysis in response to short-term variations in cortisol levels 
lasting a number of hours. Few studies have examined the effects of prolonged administration of steroids, but these suggest that the acute induction of systemic lipolysis by glucocorticoids is not sustained, even if there may be ongoing enhanced lipolysis in s.c. adipose tissue. Gravholt et al. (2002) found no change in systemic or leg adipose tissue lipolysis after 1 week of $30 \mathrm{mg}$ prednisolone/day, although s.c. abdominal adipose tissue lipolysis was increased. Miyoshi et al. (1988) administered $50 \mathrm{mg}$ / prednisolone per day for 4 days, and found no difference in the rates of intracellular re-esterification or systemic lipolysis. Similarly, Johnston et al. (1982) found no difference in NEFA concentrations, a surrogate marker of lipolysis, during partial insulin deficiency induced by somatostatin following 36-60 h of $1 \mathrm{mg}$ tetracosactrin daily.

Patients with Cushing's syndrome are heterogeneous in their characteristics and degree of glucocorticoid excess. However, consistent with the lack of effect of more than a few hours of glucocorticoid administration on systemic lipolysis in healthy volunteers, tracer studies reveal either unaltered or reduced systemic rates of lipolysis in patients with Cushing's syndrome when expressed as an absolute rate or relative to total body mass (Birkenhager et al. 1976, Saunders et al. 1980). However, in neither of these studies was the $R_{\mathrm{a}}$ of NEFAs expressed relative to fat mass, or more specifically fat-free mass (FFM), an indicator of resting energy expenditure (REE) considered by some authors to be the main determinant of NEFA turnover. For example, an increase in NEFA turnover in obesity is only measurable when it is expressed relative to FFM rather than total body mass (reviewed by Koutsari \& Jensen 2006). Importantly, insulin levels are elevated in Cushing's patients, possibly suppressing any lipolytic tendency (Saunders et al. 1980). Subcutaneous adipose tissue lipolysis may be selectively increased in patients with Cushing's syndrome, at least when measured using microdialysis (Krsek et al. 2006), but biopsies of s.c. adipose tissue from such patients exhibit impaired lipolytic activity in vitro (RebufféScrive et al. 1988). Interestingly, LPL activity was increased in these biopsies when compared with both non-obese and obese controls, suggesting that contrasting regulation of LPL and intracellular lipolysis might explain some of the inconsistencies observed in vivo. However, LPL activity, as assessed by VLDL clearance, was unchanged following surgical treatment of Cushing's syndrome (Taskinen et al. 1983).

These somewhat inconsistent results suggest that chronic glucocorticoid excess is not associated with increased lipolysis measured at whole body level, although depot-specific increases and compensatory decreases in lipolysis cannot be excluded.

\section{Effects of glucocorticoids on DNL}

Although effects on lipolysis have attracted most research effort, altered regional lipid synthesis could also influence fat redistribution following chronic glucocorticoid excess. Insulin is the main hormone promoting fatty acid synthesis and, in contrast to their apparently opposing effects on lipolysis, glucocorticoids may act synergistically with insulin to upregulate lipogenesis. Studies of adrenalectomised rats suggest that glucocorticoids are necessary for the lipogenic response to re-feeding after starvation (Williams \& Berdanier 1982). In vitro, glucocorticoids are necessary to potentiate the action of insulin on a number of lipogenic enzymes in rat hepatocytes (reviewed in Hillgartner et al. 1995), and synergism of insulin and dexamethasone has been shown in human adipocytes (Wang et al. 2004).

Most studies in humans have measured either whole body DNL indirectly using indirect calorimetry, or have specifically examined the contribution of hepatic DNL to VLDL secretion. Traditionally, DNL has been thought to make only a minimal contribution to adipose tissue TAGs, with the majority of NEFAs being derived from the diet, and until recently in vivo tracer studies examining DNL in adipose tissue have been lacking due to methodological considerations (Strawford et al. 2004). However, recent studies using prolonged (5-9 weeks) deuterated water administration, suggest that $\sim 20 \%$ of newly deposited adipose TAGs are derived from DNL in non-obese subjects (Strawford et al. 2004). Further evidence of the importance of DNL is provided by recent findings in non-alcoholic fatty liver disease, a component of the metabolic syndrome, demonstrating that an increased proportion of hepatic TAG is derived from hepatic DNL and is associated with elevated rates of fasting DNL (Donnelly et al. 2005). Glucocorticoids increase rates of hepatic DNL contributing to VLDL, reducing the contribution from the stored cytosolic TAG pool, thereby potentially contributing to hepatic steatosis and to increased export of TAGs to adipose tissue depots (Dolinsky et al. 2004). Induction of DNL by glucocorticoids in selected adipose depots could also contribute to the obese Cushingoid phenotype, but has not yet been studied.

\section{Effects of glucocorticoids on hepatic fatty acid metabolism}

In contrast to the extensive literature describing the effects of glucocorticoids on adipose tissue lipid metabolism, investigations in the liver have focused on the effects on glucose rather than fat metabolism. In vitro studies suggest that glucocorticoids promote VLDL secretion possibly by increasing production and reducing the degradation of apolipoprotein B (Wang et al. 1995). Accordingly, VLDL production rates are elevated in Cushing's syndrome, and since VLDL clearance is unaltered this accounts for increased circulating VLDL and atherogenic LDL levels (Taskinen et al. 1983). Additionally, glucocorticoids act to increase the activity of a number of enzymes involved in hepatic TAG synthesis (Bates \& Saggerson 1979, Lau \& Roncari 1983, Pittner et al. 1985; see Fig. 2).

\section{Effects of glucocorticoids on fatty acid oxidation and energy expenditure}

In order to preserve glucose for energy provision in the CNS, glucocorticoids might be expected to increase the oxidation of NEFAs in peripheral tissues. In vitro studies suggest that 

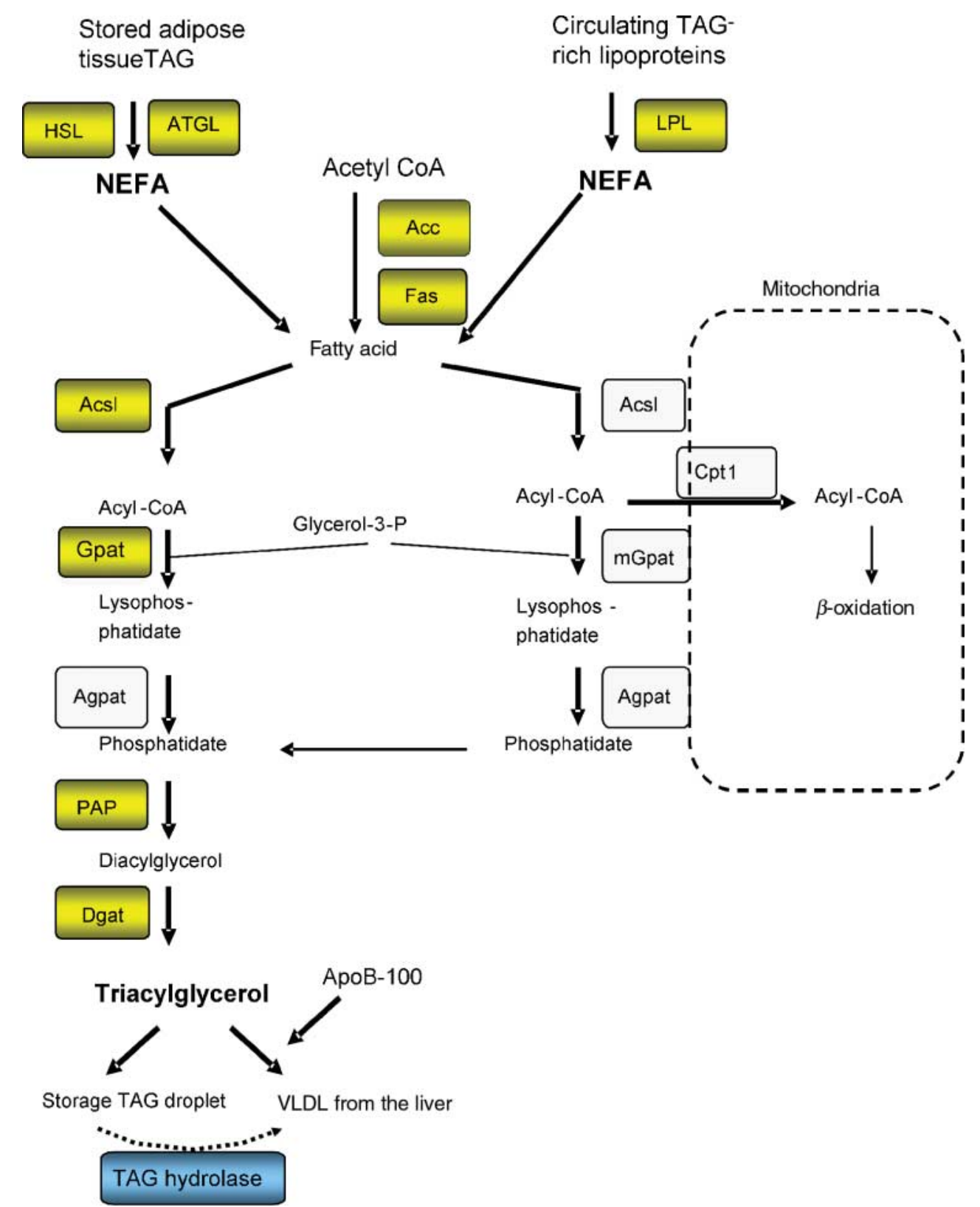

Figure 2 Enzymatic pathways involved in NEFA and TAG metabolism. Yellow indicates enzymes that are upregulated by glucocorticoids and blue indicates those which may be downregulated by glucocorticoids. Acc, acetyl-CoA carboxylase; Acsl, long chain acyl-CoA synthetase; Agpat, 1-acylglycerol-3-phosphate $O$-acyltransferase; ATGL, adipose trigylceride lipase; Cpt1, carnitine palmitoyl transferase; DAG, diacylglycerol; Dgat; DAG $O$ acyltransferase; DNL, de novo lipogenesis; Fas, fatty acid synthase; Gpat, glycerol-3-phosphate $O$-acyltransferase; HSL, hormone-sensitive lipase; LPL, lipoprotein lipase; mGpat, mitochondrial glycerol phosphate acyltransferase; PAP, phosphatidate phosphatase.

glucocorticoids have no direct effects on CPT1 activity, the essential rate-limiting enzyme required for mitochondrial $\beta$-oxidation (Agius et al. 1986), although the capacity for mitochondrial $\beta$-oxidation in muscle may be increased (Short et al. 2004), and peroxisomal $\beta$-oxidation may be increased in the liver (Norrheim et al. 1990). However, there are also some in vitro data to suggest that glucocorticoids may inhibit NEFA oxidation (Letteron et al. 1997). In vivo studies of the effects of glucocorticoids on $\beta$-oxidation have been inconclusive; these studies are problematic as altered substrate availability and compensatory hormonal changes may also influence fatty acid oxidation. For example, in one study lipid oxidation, 
measured by indirect calorimetry, was augmented by hypercortisolaemia, but this may have been secondary to increased $R_{\mathrm{a}}$ of NEFAs (Djurhuus et al. 2002).

Both REE and lipid oxidation have been shown to be unaltered in Cushing's syndrome and unchanged after successful treatment (Burt et al. 2006, 2007), whereas exogenous glucocorticoids may actually slightly increase REE (Chong et al. 1994, Brillon et al. 1995), in contrast to their effects to reduce thermogenesis in rodents (Soumano et al. 2000).

\section{Other relevant effects of glucocorticoids}

Adipocyte differentiation and cell size Compared with normal weight controls, individuals with Cushing's syndrome have an approximately two- and fivefold increase in s.c. and intraabdominal (visceral) fat respectively, although limb s.c. adipose tissue may be reduced, contributing to the classical 'lemon on sticks' description of Cushing's syndrome (Mayo-Smith et al. 1989). As well as regional differences in NEFA metabolism, changes in adipocytes size and/or number may contribute to fat redistribution, with reduced adipocyte size seen in the femoral adipose tissue in Cushing's disease (Rebuffé-Scrive et al. 1988, 1992).

Adipocyte differentiation is a complex process under the regulation of a number of transcription factors including PPAR $-\gamma$ and CCAAT/enhanced-binding proteins (Morrison \& Farmer 2000). Glucocorticoids promote the differentiation of pre-adipocytes into mature adipocytes and synergism has been demonstrated with insulin and with PPAR- $\gamma$ agonists (Hauner et al. 1987, Halvorsen et al. 2001). Certainly, rats stressed for 28 days have larger adipocytes (Rebuffe-Scrive et al. 1992) but less significant changes have been seen in humans with Cushing's syndrome (Rebuffé-Scrive et al. 1988).

Appetite and food selection Central effects of glucocorticoids on appetite are well known (reviewed in Dallman et al. 2004), and increased energy intake could clearly contribute to glucocorticoid-induced weight gain. Tataranni et al. (1996) demonstrated increased food intake in response to glucocorticoids in humans, greatly in excess of a slight increase in energy expenditure. Stimulation of appetite by glucocorticoids occurs despite elevations in the satiety hormone leptin (Udden et al. 2003). Although Tataranni et al. (1996) showed that glucocorticoids mainly stimulate protein and carbohydrate intake in humans, studies in adrenalectomised and streptozotocin-treated rodents, suggest that insulin is key in influencing food choice and increasing fat intake in response to glucocorticoids (la Fleur et al. 2004). Thus, again prevailing insulin concentrations may be important in determining the response to glucocorticoids.

\section{Glucocorticoids and fatty acid metabolism in metabolic syndrome}

Insulin resistance is the central feature of the metabolic syndrome and can precede the development of type 2 diabetes by up to 20 years (Warram et al. 1990). A key determinant of insulin resistance is the degree of obesity, in particular visceral obesity (Despres 1993). This has led to a search for factors present in people with visceral obesity, which might determine insulin resistance and hence features of metabolic syndrome. Prominent among factors released from adipose tissue, which might influence insulin resistance are adipokines, NEFAs and steroid hormones.

\section{Fatty acid metabolism in metabolic syndrome}

There is a large body of research implicating NEFAs in the pathogenesis of insulin resistance, either through direct mechanisms or via associated increased intra-myocellular lipid accumulation (Boden 1997). In fact, elevated plasma NEFAs may predict the development of type 2 diabetes (Pankow et al. 2004) independently of insulin resistance and insulin secretory defects (Charles et al. 1997). Moreover, short-term reductions in NEFAs (using the lipolysis inhibitor acipimox) can improve insulin sensitivity in obese patients with diabetes (Santomauro et al. 1999).

Over 40 years ago, Randle et al. (1963) proposed that increased NEFAs competitively inhibit the oxidation of glucose, contributing to the development of insulin resistance in rat muscle. However, more recent studies (Boden \& Shulman 2002), corroborated by in vivo magnetic resonance spectroscopy findings (Petersen \& Shulman 2002), suggest that the inhibition of glucose metabolism by NEFAs is secondary to impaired insulin signalling rather than a direct result of substrate competition, for example, NEFAs are a source of oxidative stress, activate the proinflammatory cytokine nuclear factor kappaB (NFKB), potentially interfere with insulin signalling (Itani et al. 2002) and also reduce insulin binding in vitro (Svedberg et al. 1990). Additionally, elevated NEFAs can influence rates of hepatic gluconeogenesis and VLDL secretion (Lewis et al. 1995, Chen et al. 1999), although the mechanisms contributing to this are not well understood (Krebs \& Roden 2005). Finally, the effects on pancreatic $\beta$-cells may contribute to hyperglycaemia. Elevated NEFAs are toxic to pancreatic $\beta$-cells in rodents, but in humans increasing NEFA levels within the physiological range for up to $48 \mathrm{~h}$ produced an increase in glucoseinduced insulin secretion, although clearly longer term changes may differ (Boden et al. 2001).

The source and site of pathologically important elevated NEFA levels remains controversial. A popular concept is of hyperlipolysis in visceral adipose tissue, increasing the flux of NEFAs through the portal circulation and inducing hepatic insulin resistance, but the evidence for this is not conclusive. Although visceral obesity does correlate with NEFA delivery to the liver (Nielsen et al. 2004), its contribution to systemic NEFA levels is small (Miles \& Jensen 2005). Subcutaneous adipose tissue is arguably more likely to influence peripheral insulin resistance in upper body obesity as, although visceral fat is more lipolytically active per kilogram fat than s.c. adipose tissue, the quantity of the latter is greater and 
contributes to the majority of circulating NEFAs (Basu et al. 2001). Recent studies suggest a key concept is a lack of metabolic flexibility, whereby suppression of NEFA release in the fed state is impaired in insulin-resistant subjects (Frayn 2002). A reduced intracellular capacity to switch between NEFA and glucose oxidation in response to nutrient supply is also a feature of insulin resistance, although whether this is a cause or consequence of reduced insulin sensitivity is unclear (Kelley et al. 2002).

Inhibitors of lipolysis (in humans) and NEFA oxidation (in rats) have been shown to reduce dexamethasone-induced insulin resistance (Guillaume-Gentil et al. 1993, Tappy et al. 1994). Against this background, the effects of glucocorticoids on NEFA metabolism may contribute to insulin resistance and other abnormalities in metabolic syndrome, although the hallmarks may not simply be enhanced lipolysis, but rather a more subtle deficit in metabolic flexibility in s.c. adipose tissue and perhaps in NEFA delivery to the liver from visceral adipose tissue.

\section{Glucocorticoids in metabolic syndrome}

Given their chronic effect to increase central obesity, and acute effects to enhance lipolysis, it is plausible to suggest that glucocorticoid excess might contribute to the abnormalities of NEFA metabolism observed in obesity and metabolic syndrome. Any influence of glucocorticoids on metabolic flexibility has yet to be studied, but an increased proportion of type IIb glycolytic muscle fibres, associated with metabolic inflexibility, has been shown in Cushing's syndrome (Rebuffé-Scrive et al. 1988).

There is accruing evidence that subtle abnormalities of glucocorticoid signalling are important in the pathogenesis of the complications of obesity and the metabolic syndrome. Individuals with hyperglycaemia, dyslipidaemia and hypertension have increased activation of the HPA axis (as measured by elevated fasting $0900 \mathrm{~h}$ cortisol levels, increased response to low-dose $\mathrm{ACTH}_{1-24}$ administration, and increased 24-h cortisol metabolites excretion; Phillips et al. 1998, Walker et al. 1998, Reynolds et al. 2001). The reasons for this are unclear but may relate to low birth weight and prenatal 'programming' effects (reviewed in Walker 2006). In contrast, however, in obesity plasma cortisol levels tend to be normal or low, despite elevated cortisol secretion rates. This combination is probably explained by enhanced metabolic clearance of cortisol (Walker 2006). Therefore, elevated circulating concentrations of cortisol are unlikely to play a role in linking central obesity with insulin resistance.

Tissue concentrations of cortisol are controlled not only by circulating levels but also by local metabolism. The enzyme $11 \beta-H S D 1$ amplifies local glucocorticoid levels, influencing receptor activation within tissues, and is highly expressed in adipose tissue and the liver (reviewed in Seckl \& Walker 2001, Tomlinson et al. 2004). Obese individuals have increased $11 \beta$ HSD1 mRNA transcripts and enzyme activity in s.c. adipose tissue in vitro (Rask et al. 2001, Lindsay et al. 2003, Wake et al.
2003, Kannisto et al. 2004) and increased rates of cortisol regeneration in s.c. adipose tissue in vivo (Sandeep et al. 2005). In contrast, $11 \beta-\mathrm{HSD} 1$ activity is reduced in the liver in obesity (Stewart et al. 1999, Rask et al. 2001). Whether 11 $\beta$ HSD1 is also upregulated in visceral adipose tissue in obesity is uncertain, with some studies showing increased activity (Desbriere et al. 2006, Michailidou et al. 2007) and others showing no change (Tomlinson et al. 2002, Goedecke et al. 2006, Alberti et al. 2007). Increased s.c. adipose tissue $11 \beta$ HSD1 is associated independently with markers of more severe insulin resistance (Lindsay et al. 2003) and indeed single nucleotide polymorphisms in the HSD11B1 gene encoding $11 \beta-H S D 1$ have been associated with the severity of insulin resistance and the prevalence of hypertension and diabetes independently of obesity (Franks et al. 2004, Nair et al. 2004).

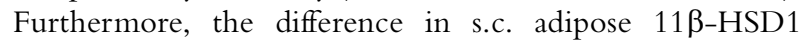
activity between obese and lean individuals is more marked in women than in men, perhaps contributing to women's higher relative risk of cardiovascular disease (Paulsen et al. 2007), although any associations between adipose tissue $11 \beta$ HSD1 activity and NEFA metabolism have not been examined in detail (Wake et al. 2003, Westerbacka et al. 2003).

It is possible that differences in glucocorticoid signalling in metabolic syndrome are a consequence rather than cause of variations in fatty acid metabolism. Although they do not appear to influence cortisol and ACTH secretion (Mai et al. 2006), plasma NEFAs and dietary macronutrient content have been shown to influence local glucocorticoid metabolism in some (Wake et al. 2006, Stimson et al. 2007) but not all human studies (Mai et al. 2005). There are also reports that NEFAs alter GR function (Sumida 1995). However, the most recent evidence supports the concept that variations in $11 \beta$-HSD1 influence fatty acid metabolism.

\section{Influence of 11 $\beta$-HSD1 on fatty acid metabolism}

Mice overexpressing 11 $\beta$-HSD1 in adipose tissue (under the aP2 promoter) develop central obesity, hypertension, dyslipidaemia and glucose intolerance (Masuzaki et al. 2001, 2003), whereas mice overexpressing $11 \beta-H S D 1$ in the liver (under the ApoE promoter) develop insulin resistance and hypertension but not obesity (Paterson et al. 2004). Conversely, $11 \beta-H S D 1$ null mice are protected from the metabolic syndrome, resisting hyperglycaemia and obesity induced by a high-fat diet, with redistribution of fat in favour of s.c. depots (Kotelevtsev et al. 1997, Morton et al. 2004). In addition to effects on glucose/insulin homeostasis, these tissue-specific manipulations of $11 \beta$-HSD1 in mice are associated with a host of alterations in fatty acid metabolism. aP2 11ß-HSD1 overexpressors have a threefold increase in plasma NEFA (as well as corticosterone) levels in the portal vein, with a less pronounced elevation in the systemic circulation (Masuzaki et al. 2001). Serum TAG levels are also increased. ApoE $11 \beta-H S D 1$ overexpressors have increased serum NEFAs on a low-fat diet (Paterson et al. 2004). In addition, hepatic gene expression studies suggest that both 
fatty acid synthesis and lipid oxidation are basally upregulated, although the lipogenic response to high-fat feeding was attenuated compared with controls (Paterson et al. 2004). In contrast, $11 \beta-H S D 1$ null mice have a favourable plasma lipoprotein profile with increased hepatic insulin sensitivity and also an apparent increase in hepatic lipid oxidation as measured by gene expression studies (Morton et al. 2001). These findings suggest that variations in glucocorticoid concentrations selectively within either the adipose tissue or the liver influence NEFA metabolism.

Pharmacological inhibition of $11 \beta-H S D 1$ as a novel therapy for type 2 diabetes is a current goal for a number of pharmaceutical companies, with promising results for glucose/ insulin homeostasis in animal models (reviewed in Stimson \& Walker 2007). Recent preclinical studies suggest that $11 \beta$ HSD1 inhibition also has beneficial effects on NEFA metabolism. In rats fed a high-fat diet, an 11 $\beta$-HSD1 inhibitor reduced serum NEFA levels, reduced mesenteric adipose tissue weight, decreased adipose tissue expression of genes involved in lipid synthesis and NEFA/TAG cycling (lipolysis and re-esterification), and increased those involved in lipid oxidation (Berthiaume et al. 2007a). Activity of key lipogenic enzymes in the liver was unaltered by $11 \beta-H S D 1$ inhibition but fasting serum TAG levels were reduced through reduced VLDL secretion (Berthiaume et al. 2007b). Uptake and oxidation of TAG-derived NEFA appeared to be increased in peripheral tissues, but interestingly muscle LPL activity was not increased (Berthiaume et al. 2007b). 11ß-HSD1 inhibitors also improve the serum lipoprotein profile and reduce the progression of atherogenesis (Hermanowski-Vosatka et al. 2005).

No specific 11 $\beta$-HSD1 inhibitors are currently licensed for human use. However, carbenoxolone, a derivative of liquorice, and non-specific inhibitor of $11 \beta-H S D 1$ and $11 \beta-H S D 2$ has been used in human studies. Short-term use in patients with diabetes and lean volunteers improved hepatic insulin sensitivity measured by euglycaemic hyperinsulinaemic clamp (Walker et al. 1995, Andrews et al. 2003), although no effect was seen in non-diabetic obese individuals (Sandeep et al. 2005). Fatty acid metabolism was not assessed in detail in these early studies with carbenoxolone, but insulin-induced suppression of plasma NEFAs was not altered, albeit that minor changes in lipoprotein profiles were observed (Andrews et al. 2003) consistent with effects in obese Zucker rats (Livingstone \& Walker 2003) and in LDL receptor knockout mice (Nuotio-Antar et al. 2007). Recently, the effects of carbenoxolone on s.c. adipose tissue lipolysis were assessed for the first time in humans by Tomlinson et al. (2007). Interstitial glycerol concentrations were reduced following carbenoxolone treatment, suggesting reduced adipose tissue lipolysis (Tomlinson et al. 2007), but systemic prednisone was administered in advance of these measurements so that it is unclear if carbenoxolone's effects are mediated within the adipose tissue or on systemic prednisone/prednisolone interconversion.

These findings with $11 \beta$-HSD1 inhibitors support the concept that glucocorticoids are important determinants of fatty acid metabolism in both animals and humans, although more detailed investigation is required to dissect the integrated effects of observed variations in gene expression upon fatty acid trafficking and metabolism.

\section{Conclusions and hypotheses}

In recent years, our understanding of the complexities of fatty acid metabolism and of glucocorticoid signalling has greatly improved. Based on the key studies summarised in Table 1, it is clear that glucocorticoids have important acute and longterm effects on fatty acid metabolism, but the data available at present are not conclusive and we are still at the stage of

Table 1 Effects of glucocorticoids on non-esterified fatty acid (NEFA) metabolism. Main references are in parentheses

\section{In vivo in humans}

\begin{tabular}{|c|c|c|c|c|}
\hline & In vitro & Acute & Chronic & $11 \beta$-HSD1 inhibition \\
\hline Adipose & $\begin{array}{l}\uparrow \text { (Baxter \& Forsham 1972, } \\
\text { Slavin et al. 1994, } \\
\text { Villena et al. 2004) }\end{array}$ & $\uparrow$ (Divertie et al. 1991) & $\begin{array}{c}\uparrow^{\mathrm{a}}(\text { Gravholt et al. 2002, } \\
\text { Krsek et al. 2006), } \leftrightarrow \\
\text { (Saunders et al. 1980, } \\
\text { Miyoshi et al. 1988), } \downarrow \\
\text { (Birkenhager et al. 1976) }\end{array}$ & $\downarrow$ (Berthiaume et al. 2007a) \\
\hline Intravascular & $\begin{array}{l}\uparrow \text { (Rebuffé-Scrive et al. } \\
\text { 1988, Appel \& Fried } \\
\text { 1992, Fried et al. 1993) }\end{array}$ & $\uparrow($ Samra et al. 1996a) & $? \uparrow^{b}$ & $\begin{array}{r}\leftrightarrow \text { In adipose } \uparrow \text { in muscle } \\
\quad(\text { Berthiaume et al. 2007a) }\end{array}$ \\
\hline De novo lipogenesis & $\begin{array}{l}\uparrow \text { (Williams \& Berdanier } \\
\text { 1982), (Hillgartner et al. } \\
\text { 1995, Wang et al. 2004) }\end{array}$ & Unknown & Unknown & $\begin{array}{l}\downarrow \text { In adipose } \leftrightarrow \text { in liver } \\
\quad(\text { Berthiaume et al. 2007a) }\end{array}$ \\
\hline Oxidation & $\begin{array}{l}? \uparrow(\text { Short et al. 2004), } \downarrow \\
\quad(\text { Letteron et al. 1997) }\end{array}$ & $\uparrow($ Djurhuus et al. 2002) & $\leftrightarrow($ Burt et al. 2006, 2007) & $\uparrow$ (Berthiaume et al. 2007a) \\
\hline VLDL export & $\uparrow($ Wang et al. 1995) & Unknown & $\uparrow$ (Taskinen et al. 1983) & $\downarrow$ (Berthiaume et al. 2007b) \\
\hline
\end{tabular}

${ }^{\mathrm{a}}$ Effects may be adipose tissue depot specific.

${ }^{\mathrm{b}}$ Chronic effects may relate to counter-regulatory hormonal changes. 
speculating on how specific pathways that respond to glucocorticoids in vitro and in animal models are integrated into the physiological responses to glucocorticoids in vivo. Our working hypotheses for the integrated role of glucocorticoids are as follows.

An acute increase in glucocorticoids, for example, during stress, increases NEFA uptake and spillover (via LPL), and turnover (lipolysis and re-esterification) of NEFAs/TAGs, while also stimulating DNL and hepatic VLDL-TAG synthesis and release. Any effect on mitochondrial oxidation of NEFAs is uncertain. The result is a 'hyperdynamic' fatty acid system, with the net effects on NEFA/TAG balance dependent on prevailing insulin and catecholamine concentrations. During fasting and with the additional stimulus of elevated catecholamines and other lipolytic counter-regulatory hormones (e.g. $\mathrm{GH})$ during stress, there is net adipose tissue lipolysis and release of NEFAs into the circulation. If feeding occurs, there is resistance to insulin-stimulated TAG storage in adipose tissue so that net NEFA release is sustained and TAG storage is discouraged. These lipolytic effects are even more marked when insulin levels fail to compensate for associated insulin resistance.

However, during recovery from stress, catecholamine and other acute counter-regulatory responses diminish, yet glucocorticoid effects are sustained, and re-feeding is associated with hyperinsulinaemia. The hyperinsulinaemia is aggravated by the effects of glucocorticoids on glucose homeostasis, inducing insulin resistance. The consequences are that adipose tissue lipolysis is diminished (in the absence of elevated catecholamines) in favour of continued hepatic release of TAGs, ongoing activation of intravascular lipolysis by LPL (upregulated by glucocorticoids and insulin), and a potentially more dynamic intracellular lipolysis/re-esterification turnover for which the set point is now in favour of TAG storage (because of the fall in catecholamines and elevated insulin levels). Additionally, glucocorticoids stimulate appetite, providing further TAG supply to LPL in chylomicrons. Crucially, however, different adipose depots may have different sensitivity to the various factors involved in adjusting the set point of this hyperdynamic fatty acid metabolism. Thus, during recovery from stress, net NEFA release is sustained from s.c. adipose tissue while net TAG storage is established in visceral adipose tissue; overall systemic lipolysis is balanced and hence not measurably altered. In teleological terms, this can be interpreted as storing energy in the more dynamically responsive visceral adipose tissue depot, ready for rapid release should recovery from stress be interrupted and a rise in catecholamines and fall in insulin provoke net systemic lipolysis once again.

Chronic glucocorticoid excess, that is, Cushing's syndrome, demonstrates the consequences of continued glucocorticoid excess in the presence of normal or low counter-regulatory lipolytic hormones and sustained hyperinsulinaemia. The results mirror those during recovery from stress rather than during acute stress, with spillover from hydrolysis of circulating TAG and net release of NEFAs from s.c. adipose tissue but continued re-esterification and storage in visceral adipose tissue. In animals which lose, rather than gain, body weight and fat with chronic glucocorticoid excess, the balance of effects of glucocorticoids on appetite, insulin resistance and depot-specific NEFA turnover is probably responsible for sustaining a pattern of fatty acid metabolism more akin to that in acute stress rather than that during recovery from stress.

In people with obesity and metabolic syndrome, the consequences of altered glucocorticoid action are likely to depend on the tissues exposed to increased cortisol concentrations. In obesity, plasma cortisol levels are not elevated and increased 11ß-HSD1 expression may be relatively restricted to s.c. adipose tissue; indeed, the liver has downregulated 11ß-HSD1 and probably lower intracellular cortisol concentrations. Elevated intra-adipose cortisol levels may increase LPL, intravascular lipolysis and spillover. However, the effects on intracellular lipolysis/ re-esterification will depend on prevailing insulin and catecholamines; if the local insulin resistance is insufficiently compensated for by hyperinsulinaemia the net effect may be to release NEFAs to the circulation. This process may contribute to metabolic inflexibility, which is closely related to insulin resistance and described in s.c. adipose tissue (Frayn 2002). However, in the absence of glucocorticoid excess in the liver and uncertain glucocorticoid exposure in visceral adipose tissue, the distribution and storage of NEFAs released from s.c. adipose tissue may not mirror that which occurs in Cushing's syndrome, explaining the lack of association between s.c. adipose tissue $11 \beta-H S D 1$ and visceral body fat distribution (Rask et al. 2001, Lindsay et al. 2003, Wake et al. 2003). In contrast, inhibitors of $11 \beta-H S D 1$ will lower cortisol concentrations in many sites where the enzyme is expressed, including liver and visceral adipose tissue, potentially ameliorating all features associated with Cushing's syndrome.

These hypotheses need to be tested, of course, using the emerging technology that allows more detailed investigation of fatty acid metabolism (e.g. depot-specific measurements of NEFA turnover, VLDL export, DNL, etc.) and with thoughtful manipulations of glucocorticoid exposure, including using emerging selective $11 \beta$-HSD1 inhibitors. Crucially, the current literature justifies further investigation of glucocorticoid signalling both as a potential driver of tissuespecific abnormalities of fatty acid metabolism seen in the metabolic syndrome and as a therapeutic target.

\section{Acknowledgements}

The authors' research is funded principally by the British Heart Foundation, Diabetes UK and the Wellcome Trust. This review describes some of the work presented in Brian Walker's 2007 Society for Endocrinology Medal Lecture entitled 'Glucocorticoids and cardiovascular disease - from cradle to grave'. The authors declare that there is no conflict of interest that would prejudice the impartiality of this scientific work. 


\section{References}

Addison T 1855 On the Constitutional and Local Effects of Disease of the SupraRenal Capsules., London: reprinted by S Highley.

Agius L, Chowdhury MH \& Alberti KG 1986 Regulation of ketogenesis, gluconeogenesis and the mitochondrial redox state by dexamethasone in hepatocyte monolayer cultures. Biochemical Journal 239 593-601.

Alberti L, Girola A, Gilardini L, Conti A, Cattaldo S, Micheletto G \& Invitti C 2007 Type 2 diabetes and metabolic syndrome are associated with increased expression of $11 \beta$-hydroxysteroid dehydrogenase 1 in obese subjects. International Journal of Obesity 31 1826-1831.

Andrews RC \& Walker BR 1999 Glucocorticoids and insulin resistance: old hormones, new targets. Clinical Science 96 513-523.

Andrews RC, Rooyackers O \& Walker BR 2003 Effects of the 11ßhydroxysteroid dehydrogenase inhibitor carbenoxolone on insulin sensitivity in men with type 2 diabetes. Journal of Clinical Endocrinology and Metabolism 88 285-291.

Appel B \& Fried SK 1992 Effects of insulin and dexamethasone on lipoprotein lipase in human adipose tissue. American Journal of Physiology 262 E695-E699.

Basu A, Basu R, Shah P, Vella A, Rizza RA \& Jensen MD 2001 Systemic and regional free fatty acid metabolism in type 2 diabetes. American Journal of Physiology. Endocrinology and Metabolism 280 E1000-E1006.

Bates EJ \& Saggerson ED 1979 A study of the glycerol phosphate acyltransferase and dihydroxyacetone phosphate acyltransferase activities in rat liver mitochondrial and microsomal fractions. Relative distribution in parenchymal and non-parenchymal cells, effects of $\mathrm{N}$-ethylmaleimide, palmitoyl-coenzyme A concentration, starvation, adrenalectomy and antiinsulin serum treatment. Biochemical Journal 182 751-762.

Baxter JD \& Forsham PH 1972 Tissue effects of glucocorticoids. American Journal of Medicine 53 573-589.

Berdanier CD 1989 Role of glucocorticoids in the regulation of lipogenesis. FASEB Journal 3 2179-2183.

Berthiaume M, Laplante M, Festuccia W, Gelinas Y, Poulin S, Lalonde J, Joanisse DR, Thieringer R \& Deshaies Y 2007a Depot-specific modulation of rat intrabdominal adipose tissue lipid metabolism by pharmacological inhibition of 11beta-hydroxysteroid dehydrogenase type 1. Endocrinology 148 2391-2397.

Berthiaume M, Laplante M, Festuccia WTL, Cianflone K, Turcotte LP, Joanisse DR, Olivecrona G, Thieringer R \& Deshaies Y 2007b 11 $\beta$-HSD1 inhibition improves triglyceridemia through reduced liver VLDL secretion and partitions lipids towards oxidative tissues. American Journal of Physiology. Endocrinology and Metabolism 293 E1045-E1052.

Birkenhager JC, Timmermans HA \& Lamberts SW 1976 Depressed plasma FFA turnover rate in Cushing's syndrome. Journal of Clinical Endocrinology and Metabolism 42 28-32.

Blaak EE, Van Baak MA, Kemerink GJ, Pakbiers MT, Heidendal GA \& Saris WH 1994 Beta-adrenergic stimulation of energy expenditure and forearm skeletal muscle metabolism in lean and obese men. American Journal of Physiology 267 E306-E315.

Boden G 1997 Role of fatty acids in the pathogenesis of insulin resistance and NIDDM. Diabetes 46 3-10.

Boden G \& Shulman GI 2002 Free fatty acids in obesity and type 2 diabetes: defining their role in the development of insulin resistance and beta-cell dysfunction. European Journal of Clinical Investigation 32 (Suppl. 3) 14-23.

Boden G, Chen X, Capulong E \& Mozzoli M 2001 Effects of free fatty acids on gluconeogenesis and autoregulation of glucose production in type 2 diabetes. Diabetes 50 810-816.

Brillon DJ, Zheng B, Campbell RG \& Matthews DE 1995 Effect of cortisol on energy expenditure and amino acid metabolism in humans. American Journal of Physiology 268 E501-E513.

Burt MG, Gibney J \& Ho KK 2006 Characterization of the metabolic phenotypes of Cushing's syndrome and growth hormone deficiency: a study of body composition and energy metabolism. Clinical Endocrinology 64 436-443.

Burt MG, Gibney J \& Ho KKY 2007 Protein metabolism in glucocorticoid excess: study in Cushing's syndrome and the effect of treatment. American Journal of Physiology. Endocrinology and Metabolism 292 E1426-E1432.
Campbell PJ, Carlson MG, Hill JO \& Nurjhan N 1992 Regulation of free fatty acid metabolism by insulin in humans: role of lipolysis and reesterification. American Journal of Physiology 263 E1063-E1069.

Charles MA, Eschwege E, Thibult N, Claude JR, Warnet JM, Rosselin GE, Girard J \& Balkau B 1997 The role of non-esterified fatty acids in the deterioration of glucose tolerance in Caucasian subjects: results of the Paris Prospective Study. Diabetologia 40 1101-1106.

Chen X, Iqbal N \& Boden G 1999 The effects of free fatty acids on gluconeogenesis and glycogenolysis in normal subjects. Journal of Clinical Investigation 103 365-372.

Chong PK, Jung RT, Scrimgeour CM \& Rennie MJ 1994 The effect of pharmacological dosages of glucocorticoids on free living total energy expenditure in man. Clinical Endocrinology 40 577-581.

Clerc D, Wick H \& Keller U 1986 Acute cortisol excess results in unimpaired insulin action on lipolysis and branched chain amino acids, but not on glucose kinetics and C-peptide concentrations in man. Metabolism 35 404-410.

Coppack SW, Evans RD, Fisher RM, Frayn KN, Gibbons GF, Humphreys SM, Kirk ML, Potts JL \& Hockaday TD 1992 Adipose tissue metabolism in obesity: lipase action in vivo before and after a mixed meal. Metabolism 41 264-272.

Coppack SW, Jensen MD \& Miles JM 1994 In vivo regulation of lipolysis in humans. Journal of Lipid Research 35 177-193.

Cushing H 1912 The Pituitary Body and its Disorders., Philadelphia and London: Lippincott.

Dallman MF, Strack AM, Akana SF, Bradbury MJ, Hanson ES, Scribner KA \& Smith M 1993 Feast and famine: critical role of glucocorticoids with insulin in daily energy flow. Frontiers in Neuroendocrinology 14 303-347.

Dallman MF, la Fleur SE, Pecoraro NC, Gomez F, Houshyar H \& Akana SF 2004 Minireview: glucocorticoids - food intake, abdominal obesity, and wealthy nations in 2004. Endocrinology 145 2633-2638.

Desbriere R, Vuaroqueaux V, Achard V, Boullu-Ciocca S, Labuhn M, Dutour A \& Grino M 2006 11 $\beta$-hydroxysteroid dehydrogenase type $1 \mathrm{mRNA}$ is increased in both visceral and subcutaneous adipose tissue of obese patients. Obesity 14 794-798.

Despres JP 1993 Abdominal obesity as important component of insulinresistance syndrome. Nutrition 9 452-459.

Dinneen S, Alzaid A, Miles J \& Rizza R 1993 Metabolic effects of the nocturnal rise in cortisol on carbohydrate metabolism in normal humans. Journal of Clinical Investigation 92 2283-2290.

Divertie GD, Jensen MD \& Miles JM 1991 Stimulation of lipolysis in humans by physiological hypercortisolemia. Diabetes 40 1228-1232.

Djurhuus CB, Gravholt CH, Nielsen S, Mengel A, Christiansen JS, Schmitz OE \& Moller N 2002 Effects of cortisol on lipolysis and regional interstitial glycerol levels in humans. American Journal of Physiology. Endocrinology and Metabolism 283 E172-E177.

Djurhuus CB, Gravholt CH, Nielsen S, Pedersen SB, Moller N \& Schmitz O 2004 Additive effects of cortisol and growth hormone on regional and systemic lipolysis in humans. American Journal of Physiology. Endocrinology and Metabolism 286 E488-E494.

Dolinsky VW, Douglas DN, Lehner R \& Vance DE 2004 Regulation of the enzymes of hepatic microsomal triacylglycerol lipolysis and re-esterification by the glucocorticoid dexamethasone. Biochemical Journal 378 967-974.

Donnelly KL, Smith CI, Schwarzenberg SJ, Jessurun J, Boldt MD \& Parks EJ 2005 Sources of fatty acids stored in liver and secreted via lipoproteins in patients with nonalcoholic fatty liver disease. Journal of Clinical Investigation 115 1343-1351.

Edens NK, Leibel RL \& Hirsch J 1990 Mechanism of free fatty acid re-esterification in human adipocytes in vitro. Journal of Lipid Research 31 1423-1431

Edwards CRW, Stewart PM, Burt D, Brett L, McIntyre MA, Sutanto WS, DeKloet ER \& Monder C 1988 Localisation of $11 \beta$-hydroxysteroid dehydrogenase- tissue specific protector of the mineralocorticoid receptor. Lancet ii 986-989.

Elliott P, Peters RF \& White AM 1971 A study of the relationship between glucocorticoid-induced weight loss in rats and the activity of skeletalmuscle and cardiac-muscle ribosomes in vitro. Biochemical Journal $\mathbf{1 2 5}$ 106P-107P. 
Fielding BA \& Frayn KN 1998 Lipoprotein lipase and the disposition of dietary fatty acids. British Journal of Nutrition 80 495-502.

la Fleur SE, Akana SF, Manalo SL \& Dallman MF 2004 Interaction between corticosterone and insulin in obesity: regulation of lard intake and fat stores. Endocrinology 145 2174-2185.

Franks PW, Knowler WC, Nair S, Koska J, Lee Y-H, Lindsay RS, Walker BR, Looker HC, Permana PA, Tataranni PA et al. 2004 Interaction between an $11 \beta \mathrm{HSD} 1$ gene variant and birth era modifies the risk of hypertension in Pima Indians. Hypertension 44 681-688.

Frayn KN 2002 Adipose tissue as a buffer for daily lipid flux. Diabetologia 45 1201-1210.

Frayn KN, Fielding BA \& Summers LK 1997 Investigation of human adipose tissue metabolism in vivo. Journal of Endocrinology 155 187-189.

Fried SK, Russell CD, Grauso NL \& Brolin RE 1993 Lipoprotein lipase regulation by insulin and glucocorticoid in subcutaneous and omental adipose tissues of obese women and men. Journal of Clinical Investigation 92 2191-2198.

Garfinkel AG, Nilsson-ehle P \& Schotz MC 1976 Regulation of lipoprotein lipase. Induction by insulin. Biochimica et Biophysica Acta 424 264-273.

Gibbons GF, Brown AM, Wiggins D \& Pease R 2002 The roles of insulin and fatty acids in the regulation of hepatic very-low-density lipoprotein assembly. Journal of the Royal Society of Medicine 95 (Suppl. 42) 23-32.

Gibbons GF, Wiggins D, Brown AM \& Hebbachi AM 2004 Synthesis and function of hepatic very-low-density lipoprotein. Biochemical Society Transactions 32 59-64.

Goedecke JH, Wake DJ, Levitt NS, Lambert EV, Collins MR, Morton NM, Andrew R, Seckl JR \& Walker BR 2006 Glucocorticoid metabolism within superficial subcutaneous rather than visceral adipose tissue is associated with features of the metabolic syndrome in South African women. Clinical Endocrinology 65 81-87.

Gravholt CH, Dall R, Christiansen JS, Moller N \& Schmitz O 2002 Preferential stimulation of abdominal subcutaneous lipolysis after prednisolone exposure in humans. Obesity Research 10 774-781.

Guillaume-Gentil C, Assimacopoulos-Jeannet F \& Jeanrenaud B 1993 Involvement of non-esterified fatty acid oxidation in glucocorticoidinduced peripheral insulin resistance in vivo in rats. Diabetologia 36 899-906.

van Hall G, Steensberg A, Sacchetti M, Fischer C, Keller C, Schjerling P, Hiscock N, Moller K, Saltin B, Febbraio MA et al. 2003 Interleukin-6 stimulates lipolysis and fat oxidation in humans. Journal of Clinical Endocrinology and Metabolism 88 3005-3010.

Halvorsen YD, Bond A, Sen A, Franklin DM, Lea-Currie YR, Sujkowski D, Ellis PN, Wilkison WO \& Gimble JM 2001 Thiazolidinediones and glucocorticoids synergistically induce differentiation of human adipose tissue stromal cells: biochemical, cellular, and molecular analysis. Metabolism 50 407-413.

Hauner H, Schmid P \& Pfeiffer EF 1987 Glucocorticoids and insulin promote the differentiation of human adipocyte precursor cells into fat cells. Journal of Clinical Endocrinology and Metabolism 64 832-835.

Heaney AP, Harper R, Ennis C, Rooney DP, Sheridan B, Atkinson AB \& Bell PM 1997 Insulin action and hepatic glucose cycling in Cushing's syndrome. Clinical Endocrinology 46 735-743.

Hellerstein MK 1999 De novo lipogenesis in humans: metabolic and regulatory aspects. European Journal of Clinical Nutrition 53 S53-S65.

Hermanowski-Vosatka A, Balkovec JM, Cheng K, Chen HY, Hernandez M, Koo GC, Le Grand CB, Li Z, Metzger JM, Mundt SS et al. 2005 11ß-HSD1 inhibition ameliorates metabolic syndrome and prevents progression of atherosclerosis in mice. Journal of Experimental Medicine 202 517-527.

Hillgartner FB, Salati LM \& Goodridge AG 1995 Physiological and molecular mechanisms involved in nutritional regulation of fatty acid synthesis. Physiological Reviews 75 47-76.

Hollingdal M, Juhl CB, Dall R, Sturis J, Veldhuis JD, Schmitz O \& Porksen N 2002 Glucocorticoid induced insulin resistance impairs basal but not glucose entrained high-frequency insulin pulsatility in humans. Diabetologia 45 49-55.

Itani SI, Ruderman NB, Schmieder F \& Boden G 2002 Lipid-induced insulin resistance in human muscle is associated with changes in diacylglycerol,

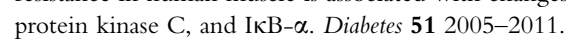

Jaworski K, Sarkadi-Nagy E, Duncan R, Ahmadian M \& Sul HS 2007 Hormonal regulation of lipolysis in adipose tissue. American Journal of Physiology. Gastrointestinal and Liver Physiology 293 G1-G4.

Jensen MD 2003 Cytokine regulation of lipolysis in humans? Journal of Clinical Endocrinology and Metabolism 88 3003-3004.

Johnston DG, Gill A, Orskov H, Batstone GF \& Alberti KG 1982 Metabolic effects of cortisol in man - studies with somatostatin. Metabolism 31 312-317.

Kalant D \& Cianflone K 2004 Regulation of fatty acid transport. Current Opinion in Lipidology 15 309-314.

Kannisto K, Pietilainen KH, Ehrenborg E, Rissanen A, Kaprio J, Hamsten A \& Yki-Jarvinen H 2004 Overexpression of 11beta-hydroxy steroid dehydrogenase- 1 in adipose tissue is associated with acquired obesity and features of insulin resistance: studies in young adult monozygotic twins. Journal of Clinical Endocrinology and Metabolism 89 4414-4421.

Kelley DE, Goodpaster BH \& Storlien L 2002 Muscle triglyceride and insulin resistance. Annual Review of Nutrition 22 325-346.

Kotelevtsev YV, Holmes MC, Burchell A, Houston PM, Scholl D, Jamieson PM, Best R, Brown RW, Edwards CRW, Seckl JR et al. 1997 11ß-Hydroxysteroid dehydrogenase type 1 knockout mice show attenuated glucocorticoid inducible responses and resist hyperglycaemia on obesity and stress. PNAS 94 14924-14929.

Koutsari C \& Jensen MD 2006 Thematic review series: patient-oriented research. Free fatty acid metabolism in human obesity. Journal of Lipid Research 47 1643-1650.

Kratky D, Zimmermann R, Wagner EM, Strauss JG, Jin W, Kostner GM, Haemmerle G, Rader DJ \& Zechner R 2005 Endothelial lipase provides an alternative pathway for FFA uptake in lipoprotein lipase-deficient mouse adipose tissue. Journal of Clinical Investigation 115 161-167.

Krebs M \& Roden M 2005 Molecular mechanisms of lipid-induced insulin resistance in muscle, liver and vasculature. Diabetes, Obesity and Metabolism 7 621-632.

Krsek M, Rosicka M, Nedvidkova J, Kvasnickova H, Hana V, Marek J, Haluzik M, Lai EW \& Pacak K 2006 Increased lipolysis of subcutaneous abdominal adipose tissue and altered noradrenergic activity in patients with Cushing's syndrome: an in vivo microdialysis study. Physiological Research 55 421-428.

Lacasa D, Agli B \& Giudicelli Y 1988 Permissive action of glucocorticoids on catecholamine-induced lipolysis: direct 'in vitro' effects on the fat cell $\beta$-adrenoreceptor-coupled-adenylate cyclase system. Biochemical and Biophysical Research Communications 153 489-497.

Lau DC \& Roncari DA 1983 Effects of glucocorticoid hormones on lipidsynthetic enzymes from different adipose tissue regions and from liver. Canadian Journal of Biochemistry and Cell Biology 61 1245-1250.

Letteron P, Brahimi-Bourouina N, Robin MA, Moreau A, Feldman G \& Passayre D 1997 Glucocorticoids inhibit mitochondrial matrix acyl-CoA dehydrogenases and fatty acid beta-oxidation. American Journal of Physiology 272 G1141-G1150.

Lewis GF, Uffelman KD, Szeto LW, Weller B \& Steiner G 1995 Interaction between free fatty acids and insulin in the acute control of very low density lipoprotein production in humans. Journal of Clinical Investigation 95 158-166.

Lillioja S, Foley J, Bogardus C, Mott D \& Howard BV 1986 Free fatty acid metabolism and obesity in man: in vivo in vitro comparisons. Metabolism 35 505-514.

Linder C, Chernick SS, Fleck TR \& Scow RO 1976 Lipoprotein lipase and uptake of chylomicron triglyceride by skeletal muscle of rats. American Journal of Physiology 231 860-864.

Lindsay RS, Tataranni A, Permana P, Livingstone DEW, Wake DJ \& Walker BR 2003 Subcutaneous adipose 11 $\beta$-hydroxysteroid dehydrogenase type 1 activity and mRNA levels are associated with adiposity and insulinaemia in Pima Indians and Caucasians. Journal of Clinical Endocrinology and Metabolism 88 2738-2744.

Livingstone DEW \& Walker BR 2003 Is $11 \beta$-hydroxysteroid dehydrogenase type 1 a therapeutic target? Effects of carbenoxolone in lean and obese Zucker rats Journal of Pharmacology and Experimental Therapeutics 305 167-172. 
Mai K, Kullmann V, Bobbert T, Maser-Gluth C, Mohlig M, Bahr V, Pfeiffer AFH, Spranger J \& Diederich S 2005 In vivo activity of $11 \beta$-hydroxysteroid dehydrogenase type 1 and free fatty acid-induced insulin resistance. Clinical Endocrinology 63 442-449.

Mai K, Bobbert T, Kullmann V, Andres J, Bahr V, Maser-Gluth C, Rochlitz H, Spranger J, Diederich S \& Pfeiffer AF 2006 No effect of free fatty acids on adrenocorticotropin and cortisol secretion in healthy young men. Metabolism 55 1022-1028.

Mangos G, Walker BR, Kelly JJ, Lawson J, Webb DJ \& Whitworth JA 2000 Cortisol inhibits cholinergic dilatation in the human forearm: towards an explanation for glucocorticoid-induced hypertension. American Journal of Hypertension 13 1155-1160.

Masuzaki H, Paterson J, Shinyama H, Morton NM, Mullins JJ, Seckl JR \& Flier JS 2001 A transgenic model of visceral obesity and the metabolic syndrome. Science 294 2166-2170.

Masuzaki H, Yamamoto H, Kenyon CJ, Elmquist JK, Morton NM, Paterson JM, Shinyama H, Sharp MGF, Fleming S, Mullins JJ et al. 2003 Transgenic amplification of glucocorticoid action in adipose tissue causes high blood pressure in mice. Journal of Clinical Investigation 112 83-90.

Mayo-Smith W, Hayes CW, Biller BM, Klibanski A, Rosenthal H \& Rosenthal DI 1989 Body fat distribution measured with CT: correlations in healthy subjects, patients with anorexia nervosa, and patients with Cushing syndrome. Radiology 170 515-518.

McGarry JD \& Brown NF 1997 The mitochondrial carnitine palmitoyltransferase system. From concept to molecular analysis. European Journal of Biochemistry 244 1-14.

Mead JR, Irvine SA \& Ramji DP 2002 Lipoprotein lipase: structure, function, regulation, and role in disease. Journal of Molecular Medicine 80 753-769.

Michailidou Z, Jensen MD, Dumesic DA, Chapman KE, Seckl JR, Walker BR \& Morton NM 2007 Omental 11 $\beta$-hydroxysteroid dehydrogenase 1 correlates with fat cell size independently of obesity. Obesity 15 1155-1163.

Miles JM \& Jensen MD 2005 Counterpoint: visceral adiposity is not causally related to insulin resistance. Diabetes Care 28 2326-2328.

Miyoshi H, Shulman GI, Peters EJ, Wolfe MH, Elahi D \& Wolfe RR 1988 Hormonal control of substrate cycling in humans. Journal of Clinical Investigation 81 1545-1555.

Moller N, Jorgensen JO, Schmitz O, Moller J, Christiansen J, Alberti KG \& Orskov H 1990 Effects of a growth hormone pulse on total and forearm substrate fluxes in humans. American Journal of Physiology 258 E86-E91.

Morrison RF \& Farmer SR 2000 Hormonal signaling and transcriptional control of adipocyte differentiation. Journal of Nutrition 130 3116S-3121S

Morton NM, Holmes MC, Fievet C, Staels B, Tailleux A, Mullins JJ \& Seckl JR 2001 Improved lipid and lipoprotein profile, hepatic insulin sensitivity, and glucose tolerance in $11 \beta$-hydroxysteroid dehydrogenase type 1 null mice. Journal of Biological Chemistry 276 41293-41300.

Morton NM, Paterson JM, Masuzaki H, Holmes MC, Staels B, Fievet C, Walker BR, Flier JS, Mullins JJ \& Seckl JR 2004 Novel adipose tissuemediated resistance to diet-induced visceral obesity in $11 \beta$-hydroxysteroid dehydrogenase type 1 deficient mice. Diabetes 53 931-938.

Nair S, Lee YH, Lindsay RS, Walker BR, Tataranni PA, Bogardus C, Baier LJ \& Permana PA 2004 11 $\beta$-Hydroxysteroid dehydrogenase Type 1: genetic polymorphisms are associated with Type 2 diabetes in Pima Indians independently of obesity and expression in adipocyte and muscle. Diabetologia 47 1088-1095.

Nakada MT, Stadel JM, Poksay KS \& Crooke ST 1987 Glucocorticoid regulation of beta-adrenergic receptors in 3T3-L1 preadipocytes. Molecular Pharmacology 31 377-384.

Nielsen S, Guo Z, Johnson CM, Hensrud DD \& Jensen MD 2004 Splanchnic lipolysis in human obesity. Journal of Clinical Investigation 113 1582-1588.

Norrheim L, Sorensen H, Gautvik K, Bremer J \& Spydevold O 1990 Synergistic actions of tetradecylthioacetic acid (TTA) and dexamethasone on induction of the peroxisomal beta-oxidation and on growth inhibition of Morris hepatoma cells. Both effects are counteracted by insulin. Biochimica et Biophysica Acta 1051 319-323.

Nuotio-Antar AM, Hachey DL \& Hasty AH 2007 Carbenoxolone treatment attenuates symptoms of metabolic syndrome and atherogenesis in obese, hyperlipidemic mice. American Journal of Physiology. Endocrinology and Metabolism 293 E1517-E1528.
Olofsson SO \& Boren J 2005 Apolipoprotein B: a clinically important apolipoprotein which assembles atherogenic lipoproteins and promotes the development of atherosclerosis. Journal of Internal Medicine 258 395-410.

Ong JM \& Kern PA 1989 Effect of feeding and obesity on lipoprotein lipase activity, immunoreactive protein, and messenger RNA levels in human adipose tissue. Journal of Clinical Investigation 84 305-311.

Ong JM, Simsolo RB, Saffari B \& Kern PA 1992 The regulation of lipoprotein lipase gene expression by dexamethasone in isolated rat adipocytes. Endocrinology 130 2310-2316.

Ottosson M, Marin P, Karason K, Elander A \& Bjorntorp P 1995 Blockade of the glucocorticoid receptor with RU 486: effects in vitro and in vivo on human adipose tissue lipoprotein lipase activity. Obesity Research 3 233-240.

Ottosson M, Lonnroth P, Bjorntorp P \& Eden S 2000 Effects of cortisol and growth hormone on lipolysis in human adipose tissue. Journal of Clinical Endocrinology and Metabolism 85 799-803.

Pankow JS, Duncan BB, Schmidt MI, Ballantyne CM, Couper DJ, Hoogeveen RC \& Golden SH 2004 Fasting plasma free fatty acids and risk of type 2 diabetes: the ARIC Study. Circulation 109 E120.

Paterson JM, Morton NM, Fievet C, Kenyon CJ, Holmes MC, Staels B, Seckl JR \& Mullins JJ 2004 Metabolic syndrome without obesity: hepatic overexpression of $11 \beta$-hydroxysteroid dehydrogenase type 1 in transgenic mice. PNAS 101 7088-7093.

Paulsen SK, Pedersen SB, Fisker S \& Richelsen B 2007 11ß-HSD type 1 expression in human adipose tissue: impact of gender, obesity, and fat localization. Obesity 15 1954-1960.

Pernet A, Johnston DG, Hammond V, Orskov H \& Alberti KG 1986 Interactions of stress hormones on lipid and carbohydrate metabolism in man with partial insulin deficiency. European Journal of Clinical Investigation 16 310-315.

Petersen KF \& Shulman GI 2002 Cellular mechanism of insulin resistance in skeletal muscle. Journal of the Royal Society of Medicine 95 (Suppl. 42) 8-13.

Phillips DIW, Barker DJP, Fall CHD, Whorwood CB, Seckl JR, Wood PJ \& Walker BR 1998 Elevated plasma cortisol concentrations: an explanation for the relationship between low birthweight and adult cardiovascular risk factors. Journal of Clinical Endocrinology and Metabolism 83 757-760.

Pittner RA, Fears R \& Brindley DN 1985 Interactions of insulin, glucagon and dexamethasone in controlling the activity of glycerol phosphate acyltransferase and the activity and subcellular distribution of phosphatidate phosphohydrolase in cultured rat hepatocytes. Biochemical Journal 230 525-534.

Randle PJ, Garland PB, Hales CN \& Newsholme EA 1963 The glucose fattyacid cycle. Its role in insulin sensitivity and the metabolic disturbances of diabetes mellitus. Lancet 1 785-789.

Rask E, Olsson T, Soderberg S, Andrew R, Livingstone DEW, Johnson O \& Walker BR 2001 Tissue-specific dysregulation of cortisol metabolism in human obesity. Journal of Clinical Endocrinology and Metabolism $\mathbf{8 6}$ 1418-1421.

Reaven GM \& Hoffman BB 1987 A role for insulin in the aetiology and course of hypertension. Lancet ii 435-436.

Rebuffé-Scrive M, Krotkiewski M, Elfverson J \& Bjorntorp P 1988 Muscle and adipose tissue morphology and metabolism in Cushing's syndrome. Journal of Clinical Endocrinology and Metabolism 67 1122-1128.

Rebuffé-Scrive M, Bronnegard M, Nilsson A, Eldh J, Gustafsson JA \& Bjorntorp P 1990 Steroid hormone receptors in human adipose tissues. Journal of Clinical Endocrinology and Metabolism 71 1215-1219.

Rebuffé-Scrive M, Walsh UA, McEwen B \& Rodin J 1992 Effect of chronic stress and exogenous glucocorticoids on regional fat distribution and metabolism. Physiology and Behavior 52 583-590.

Reinartz G, Angermaier A, Buchfelder M, Fahlbusch R \& Georgieff M 1995 Pre- and postoperative investigations of hepatic glucose production and leucine turnover in Cushing's disease utilizing stable isotope techniques. Hormone and Metabolic Research 27 425-431.

Reynolds RM, Walker BR, Phillips DIW, Sydall HE, Andrew R, Wood PJ \& Whorwood CB 2001 Altered control of cortisol secretion in adult men with low birthweight and cardiovascular risk factors. Journal of Clinical Endocrinology and Metabolism 86 245-250. 
Rizza RA, Mandarino LJ \& Gerich JE 1982 Cortisol-induced insulin resistance in man: impaired suppression of glucose production and stimulation of glucose utilization due to a postreceptor detect of insulin action. Journal of Clinical Endocrinology and Metabolism 54 131-138.

Rosen T, Bosaeus I, Tolli J, Lindstedt G \& Bengtsson BA 1993 Increased body fat mass and decreased extracellular fluid volume in adults with growth hormone deficiency. Clinical Endocrinology 38 63-71.

Samra JS, Clark ML, Humphreys SM, MacDonald IA, Matthews DR \& Frayn KN $1996 a$ Effects of morning rise in cortisol concentration on regulation of lipolysis in subcutaneous adipose tissue. American Journal of Physiology 271 E996-E1002.

Samra JS, Simpson EJ, Clark ML, Forster CD, Humphreys SM, MacDonald IA \& Frayn KN $1996 b$ Effects of epinephrine infusion on adipose tissue: interactions between blood flow and lipid metabolism. American Journal of Physiology. Endocrinology and Metabolism 271 E834-E839.

Samra JS, Clark ML, Humphreys SM, MacDonald IA, Bannister PA \& Frayn KN 1998 Effects of physiological hypercortisolemia on the regulation of lipolysis in subcutaneous adipose tissue. Journal of Clinical Endocrinology and Metabolism 83 626-631.

Sandeep TC, Andrew R, Homer NZM, Andrews RC, Smith K \& Walker BR 2005 Increased in vivo regeneration of cortisol in adipose tissue in human obesity and effects of the $11 \beta$-hydroxysteroid dehydrogenase type 1 inhibitor carbenoxolone. Diabetes 54 872-879.

Santomauro AT, Boden G, Silva ME, Rocha DM, Santos RF, Ursich MJ, Strassmann PG \& Wajchenberg BL 1999 Overnight lowering of free fatty acids with Acipimox improves insulin resistance and glucose tolerance in obese diabetic and nondiabetic subjects. Diabetes 48 1836-1841.

Saunders J, Hall SE \& Sonksen PH 1980 Glucose and free fatty acid turnover in Cushing's syndrome. Journal of Endocrinological Investigation 3 309-311.

Schade DS, Eaton RP \& Standefer J 1978 Modulation of basal ketone body concentration by cortisol in diabetic man. Journal of Clinical Endocrinology and Metabolism 47 519-528.

Schoenborn V, Heid IM, Vollmert C, Lingenhel A, Adams TD, Hopkins PN, Illig T, Zimmermann R, Zechner R, Hunt SC et al. 2006 The ATGL gene is associated with free fatty acids, triglycerides, and type 2 diabetes. Diabetes 55 1270-1275.

SecklJR \& Walker BR 2001 11ß-Hydroxysteroid dehydrogenase type 1 - a tissuespecific amplifier of glucocorticoid action. Endocrinology 142 1371-1376.

Shadid S \& Jensen MD 2003 Effects of pioglitazone versus diet and exercise on metabolic health and fat distribution in upper body obesity. Diabetes Care 26 3148-3152.

Short KR, Nygren J, Bigelow ML \& Nair KS 2004 Effect of short-term prednisone use on blood flow, muscle protein metabolism, and function. Journal of Clinical Endocrinology and Metabolism 89 6198-6207.

Sidossis LS, Stuart CA, Shulman GI, Lopaschuk GD \& Wolfe RR 1996 Glucose plus insulin regulate fat oxidation by controlling the rate of fatty acid entry into the mitochondria. Journal of Clinical Investigation $\mathbf{9 8}$ 2244-2250.

Slavin BG, Ong JM \& Kern PA 1994 Hormonal regulation of hormonesensitive lipase activity and mRNA levels in isolated rat adipocytes. Journal of Lipid Research 35 1535-1541.

Soumano K, Desbiens S, Rabelo R, Bakopanos E, Camirand A \& Silva JE 2000 Glucocorticoids inhibit the transcriptional response of the uncoupling protein-1 gene to adrenergic stimulation in a brown adipose cell line. Molecular and Cellular Endocrinology 165 7-15.

Spector AA 1975 Fatty acid binding to plasma albumin. Journal of Lipid Research 16 165-179.

Stewart PM, Boulton A, Kumar S, Clark PMS \& Shackleton CHL 1999 Cortisol metabolism in human obesity: impaired cortisone-cortisol conversion in subjects with central adiposity. Journal of Clinical Endocrinology and Metabolism 84 1022-1027.

Stimson RH \& Walker BR 2007 Glucocorticoids and 11ß-hydroxysteroid dehydrogenase type 1 in obesity and the metabolic syndrome. Minerva Endocrinologica 32 141-159.

Stimson RH, Johnstone AM, Homer NZ, Wake DJ, Morton NM, Andrew R, Lobley GE \& Walker BR 2007 Dietary macronutrient content alters cortisol metabolism independently of body weight changes in obese men. Journal of Clinical Endocrinology and Metabolism 92 4480-4484.
Strawford A, Antelo F, Christiansen M \& Hellerstein MK 2004 Adipose tissue triglyceride turnover, de novo lipogenesis, and cell proliferation in humans measured with $2 \mathrm{H}_{2} \mathrm{O}$. American Journal of Physiology. Endocrinology and Metabolism 286 E577-E588.

Sumida C 1995 Fatty acids: ancestral ligands and modern co-regulators of the steroid hormone receptor cell signalling pathway. Prostaglandins, Leukotrienes, and Essential Fatty Acids 52 137-144.

Svedberg J, Bjorntorp P, Smith U \& Lonnroth P 1990 Free-fatty acid inhibition of insulin binding, degradation, and action in isolated rat hepatocytes. Diabetes 39 570-574.

Tappy L, Randin D, Vollenweider P, Vollenweider L, Paquot N, Scherre U, Schneiter P, Nicod P \& Jequier E 1994 Mechanisms of dexamethasoneinduced insulin resistance in healthy humans. Journal of Clinical Endocrinology and Metabolism 79 1063-1069.

Taskinen MR, Nikkila EA, Pelkonen R \& Sane T 1983 Plasma lipoproteins, lipolytic enzymes, and very low density lipoprotein triglyceride turnover in Cushing's syndrome. Journal of Clinical Endocrinology and Metabolism $\mathbf{5 7}$ 619-626.

Tataranni PA, Larson DE, Snitker S, Young JB, Flatt JP \& Ravussin E 1996 Effects of glucocorticoids on energy metabolism and food intake in humans. American Journal of Physiology 271 E317-E325.

Tomlinson JW, Sinha B, Bujalska I, Hewison M \& Stewart PM 2002 Expression of $11 \beta$-hydroxysteroid dehydrogenase type 1 in adipose tissue is not increased in human obesity. Journal of Clinical Endocrinology and Metabolism 87 5630-5635.

Tomlinson JW, Walker EA, Bujalska IJ, Draper N, Lavery GG, Cooper MS, Hewison M \& Stewart PM 2004 11beta-Hydroxysteroid dehydrogenase type 1: a tissue-specific regulator of glucocorticoid response. Endocrine Reviews 25 831-866.

Tomlinson JW, Sherlock M, Hughes B, Hughes SV, Kilvington F, Bartlett W, Courtney R, Rejto P, Carley W \& Stewart PM 2007 Inhibition of 11betahydroxysteroid dehydrogenase type 1 activity in vivo limits glucocorticoid exposure to human adipose tissue and decreases lipolysis. Journal of Clinical Endocrinology and Metabolism 92 857-864.

Udden J, Bjorntorp P, Arner P, Barkeling B, Meurling L \& Rossner S 2003 Effects of glucocorticoids on leptin levels and eating behaviour in women. Journal of Internal Medicine 253 225-231.

Villena JA, Roy S, Sarkadi-Nagy E, Kim KH \& Sul HS 2004 Desnutrin, an adipocyte gene encoding a novel patatin domain-containing protein, is induced by fasting and glucocorticoids: ectopic expression of desnutrin increases triglyceride hydrolysis. Journal of Biological Chemistry 279 47066-47075.

Wake DJ, Rask E, Livingstone DEW, Soderberg S, Olsson T \& Walker BR 2003 Local and systemic impact of transcriptional upregulation of $11 \beta-$ hydroxysteroid dehydrogenase type 1 in adipose tissue in human obesity. Journal of Clinical Endocrinology and Metabolism 88 2983-2988.

Wake DJ, Homer NZ, Andrew R \& Walker BR 2006 Acute in vivo regulation of 11 beta-hydroxysteroid dehydrogenase type 1 activity by insulin and intralipid infusions in humans. Journal of Clinical Endocrinology and Metabolism $914682-4688$.

Walker BR 2006 Cortisol - cause and cure for metabolic syndrome? Diabetic Medicine 23 1281-1288.

Walker BR 2007 Glucocorticoids and cardiovascular disease. European Journal of Endocrinology 157 545-559.

Walker BR, Connacher AA, Lindsay RM, Webb DJ \& Edwards CRW 1995 Carbenoxolone increases hepatic insulin sensitivity in man: a novel role for 11-oxosteroid reductase in enhancing glucocorticoid receptor activation. Journal of Clinical Endocrinology and Metabolism 80 3155-3159.

Walker BR, Phillips DIW, Noon JP, Panarelli M, Best R, Edwards HE, Holton DW, Seckl JR, Webb DJ \& Watt GCM 1998 Increased glucocorticoid activity in men with cardiovascular risk factors. Hypertension 31 891-895.

Wang CN, McLeod RS, Yao Z \& Brindley DN 1995 Effects of dexamethasone on the synthesis, degradation, and secretion of apolipoprotein B in cultured rat hepatocytes. Arteriosclerosis, Thrombosis, and Vascular Biology 15 1481-1491. 
Wang Y, Jones VB, Urs S, Kim S, Soltani-Bejnood M, Quigley N, Heo YR Standridge M, Andersen B, Dhar M et al. 2004 The human fatty acid synthase gene and de novo lipogenesis are coordinately regulated in human adipose tissue. Journal of Nutrition 134 1032-1038.

Warram JH, Martin BC, Krolewski AS, Soeldner JS \& Kahn CR 1990 Slow glucose removal rate and hyperinsulinemia precede the development of type II diabetes in the offspring of diabetic parents. Annals of Internal Medicine 113 909-915.

Wei L, MacDonald TM \& Walker BR 2004 Taking glucocorticoids by prescription is associated with subsequent cardiovascular disease. Annals of Internal Medicine 141 764-770.

Westerbacka J, Yki-Jarvinen H, Vehkavaara S, Hakkinen A-M, Andrew R, Wake DJ, Seckl JR \& Walker BR 2003 Body fat distribution and cortisol metabolism in healthy men: enhanced $5 \beta$-reductase and lower cortisol/ cortisone metabolite ratios in men with fatty liver. Journal of Clinical Endocrinology and Metabolism 88 4924-4931.

Williams BH \& Berdanier CD 1982 Effects of diet composition and adrenalectomy on the lipogenic responses of rats to starvation-refeeding. Journal of Nutrition 112 534-541.

Wolfe RR \& Peters EJ 1987 Lipolytic response to glucose infusion in human subjects. American Journal of Physiology 252 E218-E223.
Yip RG \& Goodman HM 1999 Growth hormone and dexamethasone stimulate lipolysis and activate adenylyl cyclase in rat adipocytes by selectively shifting Gi alpha2 to lower density membrane fractions. Endocrinology 140 1219-1227.

Zammit VA 1999 The malonyl-CoA-long-chain acyl-CoA axis in the maintenance of mammalian cell function. Biochemical Journal 343 505-515.

Zechner R, Strauss JG, Haemmerle G, Lass A \& Zimmermann R 2005 Lipolysis: pathway under construction. Current Opinion in Lipidology 16 333-340.

Zimmermann R, Strauss JG, Haemmerle G, Schoiswohl G, BirnerGruenberger R, Riederer M, Lass A, Neuberger G, Eisenhaber F, Hermetter A et al. 2004 Fat mobilization in adipose tissue is promoted by adipose triglyceride lipase. Science 306 1383-1386.

Received in final form 30 January 2008

Accepted 28 February 2008

Made available online as an Accepted Preprint 28 February 2008 